\title{
FATE OF D-FAGOMINE AFTER ORAL ADMINISTRATION TO RATS
}

Susana Amézqueta ${ }^{\mathrm{a}^{*}}$, Sara Ramos-Romero ${ }^{\mathrm{b}}$, Carolina Martínez-Guimet $^{\mathrm{b}}$, Albert Moreno ${ }^{\mathrm{b}}$, Mercè $^{-}$ Hereu $^{\mathrm{b}}$, Josep Lluís Torres ${ }^{\mathrm{b}}$

aa Departament d'Enginyeria Química i Química Analítica and Institut de Biomedicina (IBUB), Universitat de Barcelona, Martí i Franquès 1-11, 08028 Barcelona, Spain. ${ }^{\mathrm{b}}$ Institute of Advanced Chemistry of Catalonia (IQAC-CSIC), Jordi Girona 18-26, 08034 Barcelona, Spain.

* To whom correspondence should be addressed. Phone: (+34) 934021797; Fax: (+34) 934021233; e-mail: samezqueta@ub.edu 


\section{ABSTRACT}

2 D-Fagomine is an iminosugar found in buckwheat that is capable of inhibiting the adhesion of 3 potentially pathogenic bacteria to epithelial mucosa and of reducing postprandial blood glucose 4 concentration. This paper evaluates the excretion and metabolism of orally administered D5 fagomine in rats and compares outcomes with the fate of 1-deoxynojirimycin. D-Fagomine and 16 deoxynojirimycin show similar absorption and excretion kinetics. D-Fagomine is partly absorbed $7 \quad$ (41-84\%, dose $2 \mathrm{mg} / \mathrm{kg}$ body weight) and excreted in urine within $8 \mathrm{~h}$ while non-absorbed fraction 8 is cleared in feces within 24 h. D-Fagomine is partially methylated (about $10 \%$ in urine and 3\% in

9 feces). The concentration of D-fagomine in urine from 1 to $6 \mathrm{~h}$ after administration is higher than 10 $\mathrm{mg} / \mathrm{L}$, the concentration that inhibits adhesion of Escherichia coli. Orally administered D-fagomine is partially absorbed and then rapidly excreted in urine were it reaches a concentration that may be protective against urinary tract infections.

Keywords. D-fagomine, 1-deoxynojirimycin, metabolism, Escherichia coli, urinary tract, mass spectrometry. 


\section{INTRODUCTION}

D-Fagomine and 1-deoxynojirimycin (DNJ) are polyhydroxylated piperidines, also known as iminocyclitols, azasugars or iminosugars, that are synthesized by various plants and microorganisms as secondary metabolites ${ }^{1,2}$. D-fagomine and DNJ can be found in foodstuffs such as bread, pasta and biscuits made from buckwheat ${ }^{3}$, and tea, snacks and biscuits made from mulberry ${ }^{4}$. Both of these iminocyclitols are glycosidase inhibitors with the capacity to reduce the postprandial glycemic response after oral administration of either sucrose or starch to rats and humans ${ }^{5-8}$. As D-fagomine and DNJ reduce the elevation of postprandial blood glucose they can be used as dietary supplements or functional food components to help maintain short-term homeostasis of blood glucose levels ${ }^{9}$. More recent observations have revealed that iminocyclitols may modify the composition of the gut microbiota by inhibiting bacterial adhesion to the intestinal mucosa ${ }^{7}$. It has been suggested that D-fagomine counteracts the short term metabolic alterations triggered by a high-energy-dense diet in rats ${ }^{10}$, at least in part through the reduction of a diet induced excess of gut Enterobacteriales ${ }^{11}$. Thus, D-fagomine might also be administered to prolong maintenance of metabolic homeostasis.

Absorption, distribution, metabolism and excretion (ADME) studies in animals and humans have been published of naturally and non-naturally occurring bioactive iminocyclitols such as $\mathrm{DNJ}, \mathrm{N}$ methyl-DNJ, 1-deoxymannojirimycin (DMJ), 1,4-dideoxy-1,4-imino-d-arabinitol (DAB), $N$ hydroxyethyl-DNJ (miglitol or glyset), $N$-butyl-DNJ (miglustat or zavesca) ${ }^{12-22}$. In rats, DNJ is poorly absorbed in a dose-dependent manner, distributed in the intact form and rapidly excreted in urine $^{15,16,18,23}$. The absorption and distribution of D-fagomine alone has never been reported. When administered as a minor component of an extract from mulberry twigs (Ramulus Mori, Chinese medicine) the D-fagomine absorption rate profile is similar to that of $\mathrm{DNJ}^{21}$. 
Bioanalytical methods for iminocyclitols have recently been reviewed ${ }^{24}$. Pharmacokinetics is effectively evaluated using radiolabeled derivatives. The technique is extremely sensitive but would fail to identify any putative transformation as a result of metabolism. More selective and safe hyphenated bioanalytical methods have also been developed. In particular, iminocyclitols are analyzed by hydrophilic interaction or cation exchange liquid chromatography coupled to different mass spectrometry detectors (single quadrupole $(\mathrm{Q})$, triple quadrupole (QqQ), quadrupole-ion trap (QTrap), or time-of-flight (TOF)) ${ }^{1,15-19,22}$.

The aim of this paper is to evaluate D-fagomine metabolism and excretion, and compare the results with those for DNJ: an iminocyclitol with putatively similar behavior.

\section{MATERIALS AND METHODS}

\section{Reagents}

A D-fagomine standard (assay $>98 \%$ ) was provided by Bioglane (Barcelona, Spain). DNJ was from Carbosynth (Berkshire, UK). DMDP (2,5-hydroxymethyl-3,4-dihydroxypyrrolidine), the internal standard, was purchased from IRL (Lower Hutt, New Zealand). Lichrosolv grade methanol, together with analytical grade acetic acid and ammonium hydroxide were obtained from Merck (Darmstadt, Germany). HPLC-grade water (Millipore type I water from Merck) was used to prepare all of the aqueous solutions. Solid-phase extraction (SPE) cartridges for sample purification were Spe-ed, SCX (strong cation exchange) cartridges, $100 \mathrm{mg} / \mathrm{mL}$ from Applied Separations (Allentown, PA, USA). Nylon filters $(0.45 \mu \mathrm{m})$ were obtained from Scharlab (Sentmenat, Spain). Microvette ${ }^{\circledR}$ CB 300 K2E Di-kalium-EDTA tubes were from Sarstedt (Nümbrecht, Germany), the gastric probe was from Harvard Apparatus (Holliston, MA, USA); and 25 G needles were from Novico Médica (Barcelona, Spain). 


\section{Animals, diets and in vivo tests}

Eighteen 8-week-old female Sprague-Dawley rats (Janvier, Le Genest-St-Isle, France) were housed under controlled conditions of stable humidity $(50 \% \pm 10 \%)$, and temperature $\left(22{ }^{\circ} \mathrm{C} \pm 2{ }^{\circ} \mathrm{C}\right)$ with a $12 \mathrm{~h}$ light $-12 \mathrm{~h}$ dark cycle. To minimize circadian rhythm effects, all rat handling was carried out in the morning. After overnight fasting, the rats were divided into six groups which were given single doses of D-fagomine or $\mathrm{DNJ}$, administered as aqueous solutions ( $5 \mathrm{~mL} / \mathrm{kg}$ body weight) using a gastric probe. Each group received 2.0, 10, or $100 \mathrm{mg} / \mathrm{kg}$ body weight of D-fagomine or DNJ. The rats were then placed in metabolic cages to collect urine and feces $1,2,4,6,8$ and $24 \mathrm{~h}$ after administration. Samples were kept at $-80{ }^{\circ} \mathrm{C}$ until analysis. After that, the rats were placed in standard cages and the remaining feces were collected by abdominal massage $48 \mathrm{~h}$ after administration. The handling of the animals was in full accordance with the European Union guidelines for the care and management of laboratory animals, and the pertinent permission was obtained from the CSIC Subcommittee for Bioethical Issues (ref. AGL2009-12 374-C03-03, CEEA-12-011, date of approval March 4th, 2013).

\section{Extraction and SPE clean-up}

After thawing, aliquots $(60 \mu \mathrm{L})$ of urine were extracted with $70 \%$ aqueous methanol $(5 \mathrm{~mL})$ using an orbital shaker (Intelli-mixer RM-2 device from Elmi; Riga, Latvia) for 20 min. Feces were cut longitudinally and the analytes were extracted from half of the sample also with $70 \%$ aqueous methanol (5 mL solvent/ $60 \mathrm{mg}$ feces) using the orbital shaker for $20 \mathrm{~min}$. After extraction the suspensions were centrifuged in a 5810R centrifuge from Eppendorf (Hamburg, Germany) for 3 min at $8000 \mathrm{rpm}$ and $20^{\circ} \mathrm{C}$, filtered through a $0.45-\mu \mathrm{m}$ nylon filter (Phenomenex; Torrance, CA, USA) and the filtrates were diluted with water to a known volume in a volumetric flask (10 $\mathrm{mL}$ in the case of urine; variable in the case of feces). Cation exchange SPE cartridges were conditioned with HPLC-grade methanol $(1 \mathrm{~mL})$ and water $(1 \mathrm{~mL})$. Then aliquots from the previous step were 
loaded onto the cartridges. The aliquot volumes were adjusted to equalize the response of the analysis (urine samples: 2500, 500 and $50 \mu \mathrm{L}$ from the groups administered the 2.0, 10 and 100 $\mathrm{mg} / \mathrm{kg}$ body weight doses respectively; feces samples: variable volumes depending on the dilution after the extraction step). SCX resin was then washed with water $(4 \mathrm{~mL})$ and vacuum-dried. Next, the analytes were eluted with $2 \mathrm{M}$ aqueous $\mathrm{NH}_{4} \mathrm{OH}(500 \mu \mathrm{L})$. The eluates were spiked with a DMDP solution in methanol $(100 \mu \mathrm{L}, 5 \mathrm{mg} / \mathrm{L})$. The solution was evaporated to dryness under a stream of $\mathrm{N}_{2}$ at $60^{\circ} \mathrm{C}$ and the residue was redissolved in water $(500 \mu \mathrm{L})$ and filtered through a 0.45 $\mu \mathrm{m}$ nylon filter.

\section{HPLC/ESI-QqQ-MS analysis}

Chromatography was carried out on an Acquity $\mathrm{H}$ class system (Waters; Milford, MA, USA) equipped with a quaternary pump and fitted with a TSK-Gel CM2SW cation exchange column (25 $\mathrm{cm} \times 4.6 \mathrm{~mm}$ i.d., $5 \mu \mathrm{m}$ particle size) (Tosoh Bioscience; Tokyo, Japan). The injection volume was 5 $\mu \mathrm{L}$, the column temperature $25{ }^{\circ} \mathrm{C}$ and the total analysis time $30 \mathrm{~min}$. The target compounds were separated with a binary system: $50 \mathrm{mM} \mathrm{NH}_{4} \mathrm{CH}_{3} \mathrm{COO}(\mathrm{pH} 8.5) /$ methanol (4:1), under isocratic conditions at a flow rate of $0.8 \mathrm{~mL} / \mathrm{min}$. Mass spectrometric analysis of the column effluent was carried out on a triple tandem quadrupole Xevo-TQ-S spectrometer (Waters). The ESI-MS/MS parameters were: positive polarity, a capillary voltage of $3 \mathrm{kV}$, a desolvation temperature of $600{ }^{\circ} \mathrm{C}$, a desolvation gas flow of $1000 \mathrm{~L} / \mathrm{h}, 7$ bar of nebulizer gas, with a cone voltage of $20-45 \mathrm{~V}$ depending on the analyte, and a collision energy of 20-30 V depending on the analyte (Table 1). Analysis was carried out in the multiple reaction monitoring mode (MRM) using the following quantification transitions: $164 \rightarrow 80$ (DMDP and DNJ), $148 \rightarrow 86$ (D-fagomine), $162 \rightarrow 100$ (monomethyl-D-fagomine), $176 \rightarrow 114$ (dimethyl-D-fagomine), $190 \rightarrow 128$ (trimethyl-Dfagomine), $178 \rightarrow 94$ (monomethyl-DNJ), $192 \rightarrow 108$ (dimethyl-DNJ), $206 \rightarrow 122$ (trimethylDNJ). The retention times of the analytes were $4 \mathrm{~min}$ (DNJ), $5.5 \mathrm{~min}$ (DMDP), $7.5 \mathrm{~min}$ 
111 (monomethyl-D-fagomine), $9 \mathrm{~min}$ (D-fagomine), $10 \mathrm{~min}$ (dimethyl-D-fagomine), $10.5 \mathrm{~min}$ 112 (trimethyl-D-fagomine) and 3.7 (monomethyl-DNJ). To confirm the identity of the metabolites, their exact masses were obtained using high resolution (HR) ESI-time of flight (TOF)-MS on an LCT Premier XE system (Waters) after HR separation using an HPLC Acquity system (Waters) fitted with a TSK-Gel CM2SW column.

\section{Standard solutions}

Stock standard solutions of $5 \mathrm{mg} / \mathrm{L}$ were prepared by dissolving D-fagomine, DNJ or DMDP (1.00 $\mathrm{mg})$ in methanol $(20 \mathrm{~mL})$ and then diluting 1:9 in methanol. All solutions were stored at $-20{ }^{\circ} \mathrm{C}$. To prepare the working standard solutions, the corresponding aliquots of the D-fagomine or DNJ stock solutions were mixed with the DMDP stock solution $(100 \mu \mathrm{L})$. The solvent was then evaporated to dryness under a stream of $\mathrm{N}_{2}$ and the residue was dissolved in water $(500 \mu \mathrm{L})$. These solutions were also stored at $-20^{\circ} \mathrm{C}$. The standard solutions were stable at this temperature for a period of at least 6 months.

\section{Validation of the analytical method}

As ESI techniques often suffer from matrix effects, the linear MS responses of D-fagomine/DMDP and DNJ/DMDP dissolved in water and matrix-matched solutions were evaluated and the slopes were compared. To prepare the matrix-matched solutions, urine and feces of rats that had still not been administered the iminosugars were used. These samples were subjected to the extraction and purification steps described in the 'Extraction and SPE clean-up' subsection. In the case of urine, $2500 \mu \mathrm{L}$ of the extract (the aliquot that contains the highest amount of interfering compounds) were passed through the cartridge. The eluate obtained from the SCX resin was spiked with $100 \mu \mathrm{L}$ of a DMDP solution in methanol $(5 \mathrm{mg} / \mathrm{L})$, and with different volumes of a D-fagomine + DNJ solution in methanol (5 mg/L of both compounds) to prepare a calibration curve in the range $4-83 \mathrm{mg}$ Dfagomine/L urine or $\mathrm{kg}$ feces. Each solution was evaporated to dryness under a stream of $\mathrm{N}_{2}$ at 60 
${ }^{\circ} \mathrm{C}$ and the residue was redissolved in water $(500 \mu \mathrm{L})$ and then filtered through a $0.45-\mu \mathrm{m}$ nylon filter. Calibration curves were constructed by plotting $\mathrm{A}_{\mathrm{D} \text {-fagomine or DNJ }} / \mathrm{A}_{\mathrm{DMDP}}$ against $\mathrm{D}$-fagomine or DNJ concentration for each solvent. Then the SSE was calculated according to Eq. 1. An SSE value smaller than 100 means that the matrix causes signal suppression, and a higher value means that the matrix causes signal enhancement ${ }^{25}$.

$$
\operatorname{SSE}(\%)=\frac{\text { Slope }_{\text {matrix }} \text {-matched calibration curve }}{\text { Slope }_{\text {aqueous standards calibration curve }}} \times 100
$$

In the assessment of linearity, calibration curves were plotted in the range $1.8-8300 \mathrm{mg} / \mathrm{L}$ and 8.3 - $8300 \mathrm{mg} / \mathrm{L}$ for D-fagomine and DNJ, respectively. Calibration curves with eleven calibration standards each were prepared across these ranges. All of the calibration standards were prepared using matrix matched solutions, and were spiked with the DMDP standard stock solution (100 $\mu \mathrm{L}$, $5 \mathrm{mg} / \mathrm{L}$ ). Linearity was evaluated for every analytical run batch to compensate for ESI variability. The concentration of the metabolites was expressed as DNJ of D-fagomine equivalents, due to the lack of commercial standards.

A precision and trueness study was carried out with the different matrices. The recovery study was performed by spiking the matrices with D-fagomine at three different concentrations $(67,330$ and $3300 \mathrm{mg} / \mathrm{L}$ in urine; and 130, 670 and $6700 \mathrm{mg} / \mathrm{kg}$ in feces) in triplicate in three different days. Three standard solutions of D-fagomine were prepared in methanol (200, 1000 and $10000 \mathrm{mg} / \mathrm{L})$, one for each of the three spiking levels. In the case of urine, the solvent of an aliquot $(20 \mu \mathrm{L})$ of the corresponding standard was evaporated and the residue containing D-fagomine was suspended in the matrix under study (60 $\mu \mathrm{L}$ of urine). In the case of feces, a portion $(60 \mathrm{mg})$ was spiked with an aliquot $(40 \mu \mathrm{L})$ of the corresponding standard. The feces samples were processed $24 \mathrm{~h}$ after spiking, to ensure complete evaporation of the solvent. Next, thesamples were subjected to the purification step. After elution, the eluates were spiked with the DMDP standard stock solution 
$158(100 \mu \mathrm{L}, 5 \mathrm{mg} / \mathrm{L})$ to correct for ESI variability. The solution was evaporated to dryness under a 159 stream of $\mathrm{N}_{2}$ at $60{ }^{\circ} \mathrm{C}$ and the residue was redissolved in water $(500 \mu \mathrm{L})$ and filtered through a $160 \quad 0.45-\mu \mathrm{m}$ nylon filter. In parallel, the calibration curves were prepared using matrix-matched 161 standards. Finally, the samples and the calibration standards were analyzed by LC-MS/MS. 162 Recovery was determined by comparing the $A_{D-f a g o m i n e} / A_{D M D P}$ signal obtained from the spiked samples with the $A_{D-f a g o m i n e} / A_{D M D P}$ signal from the calibration standards. Precision was evaluated by calculating the RSDs obtained in within- and between-day recovery experiments. The limit of quantification (LOQ) was established as the concentration at which a recovery value similar to that of the trueness study was obtained with an RSD $<20 \%$ when analyzing five spiked samples.

\section{RESULTS AND DISCUSSION}

\section{Set-up and validation of the analytical method}

The analytical method was adapted for biological fluids from a previously described procedure developed for the analysis of plant sources (buckwheat and mulberry) ${ }^{1}$. Modifications were introduced in the extraction step and, to improve selectivity and sensibility, triple quadrupole MS was used instead of single quadrupole MS. First, the MS parameters such as desolvation temperature, cone voltage or collision energy were optimized to improve better signal intensity for the analytes under study. Then, selectivity, sensibility and linearity were checked by preparing the D-fagomine and DNJ calibration curves using DMDP as an internal standard and two solvents: water and the matrix resulting from control urine or feces subjected to the extraction and SPE purification steps. The calibration curves generated with the two matrices showed significant signal suppression/enhancement (Table 2), so the calibration standards used from that point on were prepared using matrix-matched solutions. The assay response (area of the D-fagomine or DNJ peak divided by the area of the DMDP peak) to D-fagomine or DNJ concentration was linear $\left(\mathrm{R}^{2}>0.99\right)$ 
in the ranges under study $(1.8-8300 \mathrm{mg} / \mathrm{L}$ and $8.3-8300 \mathrm{mg} / \mathrm{L}$ for D-fagomine and DNJ, respectively). Within-day and between-day precision and trueness were studied using samples of urine and feces spiked with D-fagomine. In the case of urine, the percentage recovery at the three concentrations assayed (96\%) was homogeneous (RSD: 12\%), which demonstrated the precision and trueness of the analytical procedure. The European Medicines Agency (EMEA) ${ }^{26}$ recommends a recovery value (trueness) in the range $85 \%-115 \%$ and a relative standard deviation value (RSD; precision) of under $15 \%$ for bioanalytical methods. In the case of feces, within-day recovery was 47\% (RSD: $10 \%$ ): outside the EMEA suggested interval (85\%-115\%). Intra-day recovery was 51\% (RSD: 14\%), which demonstrated the validity of the method despite the low recovery. The results in this work are corrected for the recovery values. The LOQ values were $1.8 \mathrm{mg} / \mathrm{L}$ urine or $\mathrm{kg}$ feces, for D-fagomine; and $8.3 \mathrm{mg} / \mathrm{L}$ urine or $\mathrm{kg}$ feces, for DNJ. DNJ shows a higher LOQ value because its ionization in the MS detector was not as complete as that of D-fagomine.

The results of the validation study show that the new methods met all the requirements for a bioanalytical process ${ }^{26}$. The methods were selective; the response was linear in the working range; precision and trueness fell within the recommended range except for feces recovery; and the LOQ was much lower than the D-fagomine and DNJ concentrations found after the maximum excretion period. The methods were successfully applied to the determination of D-fagomine, DNJ and their metabolites in the urine and feces of rats fed D-fagomine or DNJ. The identity of the compounds was confirmed by HPLC/ESI-HR-TOF-MS with samples generated in a previous separate experiment by administration of $250 \mathrm{mg}$ of iminocyclitol per kg body weight (Table 3).

\section{Absorption and excretion}

The animals were administered 2.0, 10 or $100 \mathrm{mg} / \mathrm{kg}$ body weight of D-fagomine or DNJ (positive control). The dose of $2.0 \mathrm{mg} / \mathrm{kg}$ body weight corresponded to the dose of D-fagomine that reduced postprandial blood glucose concentration ( $20 \%$ reduction of the area under the curve between 0 and 

$120 \mathrm{~min}$ ) after intake of glucose or starch ${ }^{7}$. At this active concentration part of the administered Dfagomine (0.2-0.4 mg) was absorbed and excreted in urine within $8 \mathrm{~h}$, while the rest was recovered in feces within $24 \mathrm{~h}$ (Figure 1a and Table 4). Absorption appears to be limited due to saturation after a total amount of $3 \mathrm{mg}$ of D-fagomine has been absorbed (Table 4). The highest excretion rate occurred in the period between 2 and $4 \mathrm{~h}$ in urine (Figure 2 and Table 5) and in the period between 8 and $24 \mathrm{~h}$ in feces (Table 6). D-Fagomine was not detected in feces collected by abdominal massage $48 \mathrm{~h}$ after intake (Table 6). Briefly the absorbed portion of D-fagomine is cleared in urine within $8 \mathrm{~h}$ and the non-absorbed portion in feces within $24 \mathrm{~h}$ after intake. The behavior of Dfagomine and DNJ (positive control) was similar (Figure 1 and Tables 4-6) and the absorption under our experimental conditions reached saturation at a total absorbed amount of $2 \mathrm{mg}$. As most (around $90 \%$ at the 3 doses) of both of the ingested iminocyclitols is excreted, whether in urine or feces, within the first $24 \mathrm{~h}$ after oral administration these compounds probably do not accumulate in tissues, as already suggested by Nakagawa et al. (2007) ${ }^{15}$.

The results presented here for DNJ agree with two other studies that also used a pure compound 15,18. Nakagawa et al. (2007) ${ }^{15}$ found that about $0.6 \mathrm{mg}$ of the DNJ (2\%) was excreted in urine within $24 \mathrm{~h}$ after a $110 \mathrm{mg} / \mathrm{kg}$ body weight oral administration after fasting ${ }^{15}$. Kim et al. (2010) ${ }^{18}$ reported that about $4 \mathrm{mg}$ of the DNJ administered was excreted in urine within $24 \mathrm{~h}$ after a 30 $\mathrm{mg} / \mathrm{kg}$ body weight oral administration; the non-absorbed fraction was excreted in feces within 48 h. When DNJ was administered as a component of a plant extract, the excretion profile was similar to that one obtained here. Xiao et al. (2014) reported that about $2.5 \mathrm{mg}$ of DNJ in a mulberry root bark extract was excreted in urine within the first four hours ${ }^{27}$. Our results show that D-fagomine is absorbed as fast as DNJ is.

\section{Metabolism}


229 It has been reported that DNJ (positive control) is mainly excreted in the intact form ${ }^{15,16,18,27}$. 230 Nakagawa et al. (2007) did not detect any degradation products (e.g., oxidized and alkylated products) in plasma and reported that a small signal in the HPLC-MS single ion monitoring chromatogram might correspond to an unidentified metabolite ${ }^{15}$. We found trace amounts of monomethyl-DNJ in urine and several methyl derivatives of D-fagomine. A monomethylated conjugate was present in urine $(10 \%)$ and feces $(3 \%)$, at the three doses, within the period of $0-8 \mathrm{~h}$ (Figure 1a, Table 4). We also detected trace levels of dimethyl-D-fagomine and trimethyl-Dfagomine in urine, at the three doses, within the period of 0-8 h. In a preliminary experiment with samples obtained by administering a higher dose of D-fagomine (250 mg / kg body weight), signals compatible with deoxygenated products were detected that were not found at the lower concentrations used here. Metabolism of organic compounds consists mainly of their conversion into more hydrophilic species that can be readily excreted ${ }^{28}$. Phase II conjugation into glucuronides and sulfates are the most common transformations. Iminocyclitols such as D-fagomine and DNJ are already highly water soluble and they are rapidly excreted without further modification. Methylation is a less common phase II conjugation that reduces water solubility and plays the physiological role of blocking biological activities by modifying chemically active functions, such as those of amines and hydroxyls ${ }^{29}$. In the case of D-fagomine, as only a small percentage is methylated, it is unlikely that methylation serves the purpose of deactivation. Its structure may partially fit the requirements for the enzymes involved in the modification of other chemical species, most likely sugars. The presence of methyl-D-fagomine in feces could be explained by biliary excretion after modification in the liver. Alternatively, methyl-D-fagomine may be generated by the gut microbiota as some species of the phylum Actinobacteria are capable of methylating the terminal units of oligosaccharides ${ }^{30}$. 
The presence of intact D-fagomine in urine for several hours after oral ingestion may have important implications for the maintenance of a healthy status in the urinary tract. The concentration of D-fagomine in contact with the tissues along the urinary tract for the period of from 1 to $6 \mathrm{~h}$, in all the rats tested at any dose (Table 5, Figure 2) was higher than the concentration $(10 \mathrm{mg} / \mathrm{L})$ that inhibits adhesion $(95 \%)$ of Escherichia coli to the intestinal mucosa ${ }^{7}$. So, at the dose that is active at lowering postprandial glucose concentration by $20 \%(2.0 \mathrm{mg} / \mathrm{kg}$ body weight: the lowest dose tested) D-fagomine may protect against urinary tract infections. D-Fagomine may also protect the intestinal tract against infections. We recently showed that D-fagomine, at a dose of $23 \mathrm{mg} / \mathrm{kg}$ body weight/day, reduced the increase in the population of Enterobacteriales induced by a high-fat high-sucrose diet ${ }^{11}$.

To sum up, orally administered D-fagomine is rapidly absorbed and excreted in urine within $8 \mathrm{~h}$ in rats. The non-absorbed fraction is cleared in feces within $24 \mathrm{~h}$. D-fagomine is partially methylated (about $10 \%$ in urine and 3\% in feces). The concentration of D-fagomine in urine 1 to $6 \mathrm{~h}$ after oral administration of $2.0 \mathrm{mg} / \mathrm{kg}$ body weight is higher than the concentration that inhibits $(95 \%)$ the adhesion of E. coli to epithelial surfaces. Therefore, D-fagomine may protect the urinary tract against infections caused by Enterobacteriales at a dose that is active at reducing postprandial blood glucose concentration.

\section{ACKNOWLEDGEMENTS}

Our thanks go to Bioglane for providing D-fagomine; to Ms E. Galan and L. Gómez for collaborating in the preliminary study; and to Dr E. Prats, Dr R. Chaler and Ms D. Fanjul for technical support. Language assistance from Christopher Evans is appreciated. 
276 This research was funded by the Spanish Ministry of Economy and Competitiveness through a 277 research grant (AGL2013-49079-C2-2-R) and a graduate fellowship to M.H.

\section{CONFLICT OF INTEREST}

The authors declare that they have no conflict of interest.

\section{REFERENCES}

(1) Amézqueta, S.; Galán, E.; Fuguet, E.; Carrascal, M.; Abián, J.; Torres, J. L. Determination

(3) Amézqueta, S.; Galán, E.; Vila-Fernández, I.; Pumarola, S.; Carrascal, M.; Abian, J.; RibasBarba, L.; Serra-Majem, L.; Torres, J. L. The presence of D-fagomine in the human diet from buckwheat-based foodstuffs. Food Chem. 2013, 136, 1316-1321.

(4) Yoshihashi, T.; Do, H. T. T.; Tungtrakul, P.; Boonbumrung, S.; Yamaki, K. Simple, selective, and rapid quantification of 1-deoxynojirimycin in mulberry leaf products by highperformance anion-exchange chromatography with pulsed amperometric detection. J. Food Sci. 2010, 75, 246-250. 
(5) Kimura, T.; Nakagawa, K.; Kubota, H.; Kojima, Y.; Goto, Y.; Yamagishi, K.; Oita, S.; Oikawa, S.; Miyazawa, T. Food-grade mulberry powder enriched with 1-deoxynojirimycin suppresses the elevation of postprandial blood glucose in humans. J. Agric. Food Chem. 2007, 55, 5869-5874.

(6) Kong, W. H.; Oh, S. H.; Ahn, Y. R.; Kim, K. W.; Kim, J. H.; Seo, S. W. Antiobesity effects and improvement of insulin sensitivity by 1-deoxynojirimycin in animal models. J. Agric. Food Chem. 2008, 56, 2613-2619.

(7) Gómez, L.; Molinar-Toribio, E.; Calvo-Torras, M. Á.; Adelantado, C.; Juan, M. E.; Planas, J. M.; Cañas, X.; Lozano, C.; Pumarola, S.; Clapés, P.; et al. D-Fagomine lowers postprandial blood glucose and modulates bacterial adhesion. Br. J. Nutr. 2012, 107, 17391746.

(8) Bioglane SLNE. Effects of added d-fagomine on glycaemic responses to sucrose. In: ClinicalTrials.gov [Internet]. Bethesda (MD): National Library of Medicine (US). 2000[cited 2016 Des 31]. Available from: https://clinicaltrialbase.com/study/NCT01811303 NLM Identifier: NCT01811303.

(9) Giugliano, D.; Ceriello, A.; Esposito, K. Glucose metabolism and hyperglycemia. Am. J. Clin. Nutr. 2008, 87, 217S-222S.

(10) Molinar-Toribio, E.; Pérez-Jiménez, J.; Ramos-Romero, S.; Gómez, L.; Taltavull, N.; Nogués, M. R.; Adeva, A.; Jáuregui, O.; Joglar, J.; Clapés, P.; et al. Fagomine attenuates metabolic alterations induced by a high-energy-dense diet in rats. Food Funct. 2015, 6, 2614-2619.

(11) Ramos-Romero, S.; Molinar-Toribio, E.; Gómez, L.; Pérez-Jiménez, J.; Casado, M.; Clapés, 
P.; Piña, B.; Torres, J. L. Effect of D-fagomine on excreted enterobacteria and weight gain in rats fed a high-fat high-sucrose diet. Obesity 2014, 22, 976-979.

(12) Faber, E.; R, O.; Neefjes, J.; Ploegh, H.; Meijer, D. Distribution and elimination of the glycosidase inhibitors 1-deoxymannojirimycin and N-methyl-1-deoxynojirimicyn in the rat in vivo. Pharm. Res. 1992, 9, 1442-1450.

(13) Ahr, H. Pharmacokinetics of miglitol: Absorption, distribution, metabolism, and excretion following administration to rats, dogs, and man. Arzneimittelforschung. 1997, 47, 734-745.

(14) Li, X.; Wang, Y.; Wang, J.; Fawcett, J. P.; Zhao, L.; Gu, J. Determination of miglitol in human plasma by liquid chromatography/tandem mass spectrometry. Rapid Commun. Mass Spectrom. 2007, 21, 247-251.

(15) Nakagawa, K.; Kubota, H.; Kimura, T.; Tsuzuki, T.; Oikawa, S.; Miyazawa, T. Occurrence of orally administered mulberry 1-deoxynojirimycin in rat plasma. J. Agric. Food Chem. 2007, 55, 8928-8933.

(16) Nakagawa, K.; Kubota, H.; Tsuzuki, T.; Kariya, J.; Kimura, T.; Oikawa, S.; Miyazawa, T. Validation of an ion trap tandem mass spectrometric analysis of mulberry 1deoxynojirimycin in human plasma: application to pharmacokinetic studies. Biosci. Biotechnol. Biochem. 2008, 72, 2210-2213.

(17) Guitton, J.; Coste, S.; Guffon-Fouilhoux, N.; Cohen, S.; Manchon, M.; Guillaumont, M. Rapid quantification of miglustat in human plasma and cerebrospinal fluid by liquid chromatography coupled with tandem mass spectrometry. J. Chromatogr. B 2009, 877, 149154.

(18) Kim, J. Y.; Kwon, H. J.; Jung, J. Y.; Kwon, H. Y.; Baek, J. G.; Kim, Y. S.; Kwon, O. 
Comparison of absorption of 1-deoxynojirimycin from mulberry water extract in rats. $J$. Agric. Food Chem. 2010, 58, 6666-6671.

(19) Spieker, E.; Wagner-Redeker, W.; Dingemanse, J. Validated LC-MS/MS method for the quantitative determination of the glucosylceramide synthase inhibitor miglustat in mouse plasma and human plasma and its application to a pharmacokinetic study. J. Pharm. Biomed. Anal. 2012, 59, 123-129.

(20) Attimarad, M. V; Nair, A. B.; Aldhubaib, B. E. Development of liquid chromatographic method for the simultaneous determination of metformin and miglitol in human plasma: application to pharmacokinetic studies. J. Iran. Chem. Soc. 2015, 1629-1636.

(21) Yang, S.; Wang, B.; Xia, X.; Li, X.; Wang, R.; Sheng, L.; Li, D.; Liu, Y.; Li, Y. Simultaneous quantification of three active alkaloids from a traditional Chinese medicine Ramulus Mori (Sangzhi) in rat plasma using liquid chromatography-tandem mass spectrometry. J. Pharm. Biomed. Anal. 2015, 109, 177-183.

(22) Jain, R.; Lukram, O.; Dwivedi, A. Ultra-performance liquid chromatography electrospray ionization-tandem mass spectrometry method for the estimation of miglitol in human plasma using metformin as the internal standard. Drug Test. Anal. 2011, 3, 255-262.

(23) Nakagawa, K.; Ogawa, K.; Higuchi, O.; Kimura, T.; Miyazawa, T.; Hori, M. Determination of iminosugars in mulberry leaves and silkworms using hydrophilic interaction chromatography-tandem mass spectrometry. Anal. Biochem. 2010, 404, 217-222.

(24) Amézqueta, S.; Torres, J. L. Advances in the analysis of iminocyclitols: Methods, sources and bioavailability. Talanta 2016, 151, 157-171.

(25) Panuwet, P.; Hunter, R. E.; D’Souza, P. E.; Chen, X.; Radford, S. A.; Cohen, J. R.; Marder, 
M. E.; Kartavenka, K.; Ryan, P. B.; Barr, D. B. Biological matrix effects in quantitative tandem mass spectrometry-based analytical methods: advancing biomonitoring. Crit. Rev. Anal. Chem. 2016, 21, 4062-4072.

(26) EMEA. Guideline on bioanalytical method validation. EMA Guidel. 2012, 44 (July 2011).

(27) Xiao, B. X.; Wang, Q.; Fan, L. Q.; Kong, L. T.; Guo, S. R.; Chang, Q. Pharmacokinetic mechanism of enhancement by Radix Pueraria flavonoids on the hyperglycemic effects of Cortex Mori extract in rats. J. Ethnopharmacol. 2014, 151, 846-851.

(28) Levsen, K.; Schiebel, H. M.; Behnke, B.; Dötzer, R.; Dreher, W.; Elend, M.; Thiele, H. Structure elucidation of phase II metabolites by tandem mass spectrometry: An overview. $J$. Chromatogr. A 2005, 1067, 55-72.

(29) Muthana, S. M.; Campbell, C. T.; Gildersleeve, J. C. Modifications of glycans: Biological significance and therapeutic opportunities. ACS Chem. Biol. 2012, 7, 31-43.

(30) Cantoni, G. L. Biological methylation. Selected aspects. Annu. Rev. Biochem. 1975, 44, 435451. 


\section{FIGURE CAPTIONS}

378 Figure 1. Percentages of D-fagomine (a) and DNJ (b) including their methyl derivatives, excreted 379 in feces and urine after oral administration at three different doses.

380 Figure 2. D-fagomine concentration in urine after oral administration of $2.0 \mathrm{mg} / \mathrm{kg}$ body weight. 
382 Table 1. Cone Voltages and Collision Energies Applied in the ESI-MS/MS Analysis.

Cone voltage (V) Collision energy (V)

\begin{tabular}{lll}
\hline DMDP & 45 & 20 \\
DNJ & 45 & 20 \\
D-Fagomine & 35 & 20 \\
Methylfagomine & 20 & 30 \\
Dimethylfagomine & 20 & 30 \\
Trimethylfagomine & 35 & 30 \\
\hline
\end{tabular}

383

384 
385 Table 2. Signal Suppression and Enhancement Effect in Matrix-matched Solutions of Both Urine 386 and Feces.

\begin{tabular}{llll} 
& \multicolumn{1}{c}{$\begin{array}{l}\text { D-Fagomine/DMDP signal vs D- } \\
\text { fagomine concentration }\end{array}$} & $\begin{array}{l}\text { DNJ/DMDP signal vs DNJ } \\
\text { concentration }\end{array}$ \\
\hline Urine & $\begin{array}{l}\text { Aqueous standards } \\
\text { Matrix-matched }\end{array}$ & $y=0.58 x-0.4$ & $y=0.036 x-0.06$ \\
standards & $y=0.099 x-0.3$ & $y=0.0018 x-0.005$ \\
SSE (\%) & $17 \%$ (Signal suppression) & $5 \%$ (Signal suppression) \\
Feces & $\begin{array}{l}\text { Aqueous standards } \\
\text { Matrix-matched }\end{array}$ & $y=0.103 x+0.1$ & $y=0.0025 x-0.027$ \\
standards & $y=0.47 x+1$ & $y=0.010 x-0.08$ \\
SSE (\%) & $458 \%$ (Signal enhancement) & $390 \%$ (Signal enhancement) \\
\hline
\end{tabular}

$387 y$ relative abundance, $x$ concentration in $\mathrm{mg} / \mathrm{L}$ or $\mathrm{mg} / \mathrm{kg}$, SSE signal suppression enhancement 
389 Table 3. Identification of D-Fagomine Metabolites by HPLC/ESI-HR-TOF-MS.

\begin{tabular}{ccccccc}
$m / z$ & $\begin{array}{c}\text { Retention } \\
\text { time }\end{array}$ & $\begin{array}{c}\text { Measured } \\
\text { mass }\end{array}$ & $\begin{array}{c}\text { Calculated } \\
\text { mass }\end{array}$ & Formula & ppm & Compound \\
\hline 148 & 11.7 & 148.0970 & 148.0974 & $\mathrm{C}_{6} \mathrm{H}_{14} \mathrm{NO}_{3}$ & -2.0 & Fagomine \\
162 & 9.4 & 162.1129 & 162.1130 & $\mathrm{C}_{7} \mathrm{H}_{16} \mathrm{NO}_{3}$ & -0.6 & Methylfagomine \\
176 & 12.7 & 176.1282 & 176.1287 & $\mathrm{C}_{8} \mathrm{H}_{18} \mathrm{NO}_{3}$ & -2.8 & Dimethylfagomine \\
190 & 13.3 & 190.1441 & 190.1443 & $\mathrm{C}_{9} \mathrm{H}_{20} \mathrm{NO}_{3}$ & -1.1 & Trimethylfagomine \\
\hline
\end{tabular}

390 Measurements made from a sample of urine collected 1h after administration of D-fagomine (250

$391 \mathrm{mg}$ D-fagomine/kg body weight) during a preliminary pilot study with Sprague-Dawley rats.

392

393

394

395

396

397 
Table 4. Excretion of D-Fagomine and DNJ in Feces and Urine after Oral Administration.

\begin{tabular}{|c|c|c|c|c|c|c|c|c|c|}
\hline $\begin{array}{l}\text { Compound } \\
\text { (dose) }\end{array}$ & Rat & $\begin{array}{c}\mathrm{mg} \\
\text { Administere } \\
\mathrm{d}\end{array}$ & $\begin{array}{c}\text { mg excreted in } \\
\text { urine }(0-8 \mathrm{~h}) \\
\text { intact form }\end{array}$ & $\begin{array}{l}\text { mg excreted in } \\
\text { urine }(0-8 \mathrm{~h}), \\
\text { methylated form }\end{array}$ & $\begin{array}{c}\text { mg excreted in } \\
\text { feces }(6-24 \mathrm{~h}), \\
\text { intact form }\end{array}$ & $\begin{array}{l}\text { mg excreted in } \\
\text { feces }(6-24 \mathrm{~h}), \\
\text { methylated form }\end{array}$ & $\begin{array}{c}\% \text { excreted } \\
\text { in urine }(0- \\
8 \mathrm{~h})\end{array}$ & $\begin{array}{c}\% \text { excreted } \\
\text { in feces }(6- \\
24 \mathrm{~h})\end{array}$ & $\begin{array}{c}\text { Total }(\% \\
\text { feces }+ \\
\% \text { urine })\end{array}$ \\
\hline \multirow{3}{*}{$\begin{array}{c}\text { D-Fagomine } \\
(2.0 \mathrm{mg} / \mathrm{kg} \text { body weight })\end{array}$} & 1 & 0.53 & 0.41 & 0.04 & 0.10 & - & 84 & 19 & 103 \\
\hline & 2 & 0.53 & 0.30 & 0.03 & 0.31 & 0.02 & 63 & 64 & 127 \\
\hline & 3 & 0.57 & 0.21 & 0.02 & 0.39 & 0.02 & 41 & 71 & 112 \\
\hline \multirow{3}{*}{$\begin{array}{c}\text { DNJ } \\
(2.0 \mathrm{mg} / \mathrm{kg} \text { body weight })\end{array}$} & 4 & 0.72 & 0.31 & - & - & - & 42 & - & 42 \\
\hline & 5 & 0.80 & 0.55 & - & 0.09 & - & 69 & 11 & 80 \\
\hline & 6 & 0.75 & 0.81 & - & 0.05 & - & 108 & 6 & 114 \\
\hline \multirow{3}{*}{$\begin{array}{c}\text { D-Fagomine } \\
\text { (10 mg/kg body weight) }\end{array}$} & 7 & 2.6 & 0.9 & 0.08 & 0.8 & 0.02 & 37 & 30 & 67 \\
\hline & 8 & 2.7 & 1.6 & 0.25 & 1.6 & 0.03 & 70 & 60 & 131 \\
\hline & 9 & 2.8 & 0.5 & 0.03 & 1.8 & 0.10 & 18 & 69 & 87 \\
\hline \multirow{3}{*}{$\begin{array}{c}\text { DNJ } \\
(10 \mathrm{mg} / \mathrm{kg} \text { body weight })\end{array}$} & 10 & 2.6 & 2.2 & - & 0.6 & - & 83 & 23 & 105 \\
\hline & 11 & 2.7 & 1.0 & - & 2.0 & - & 38 & 76 & 113 \\
\hline & 12 & 2.7 & 1.6 & - & 1.1 & - & 59 & 42 & 101 \\
\hline \multirow{3}{*}{$\begin{array}{c}\text { D-Fagomine } \\
(100 \mathrm{mg} / \mathrm{kg} \text { body weight })\end{array}$} & 13 & 26 & 2.3 & 0.07 & 17 & 0.52 & 9 & 66 & 75 \\
\hline & 14 & 27 & 1.2 & 0.03 & 22 & 0.53 & 5 & 85 & 90 \\
\hline & 15 & 27 & 5.4 & 0.02 & 18 & 0.95 & 20 & 69 & 89 \\
\hline \multirow{3}{*}{$\begin{array}{c}\text { DNJ } \\
(100 \mathrm{mg} / \mathrm{kg} \text { body weight })\end{array}$} & 16 & 26 & 2.4 & - & 15 & - & 9 & 56 & 65 \\
\hline & 17 & 27 & 1.4 & - & 26 & - & 5 & 95 & 101 \\
\hline & 18 & 27 & 1.7 & - & 14 & - & 6 & 53 & 60 \\
\hline
\end{tabular}


Table 5. D-Fagomine and DNJ Concentration $(\mathrm{mg} / \mathrm{L})$ in Urine during Different Periods after Oral Administration.

\begin{tabular}{|c|c|c|c|c|c|c|c|}
\hline & Rat & $0-1 \mathrm{~h}$ & $1-2 \mathrm{~h}$ & $2-4 \mathrm{~h}$ & $4-6 \mathrm{~h}$ & $6-8 \mathrm{~h}$ & $8-24 \mathrm{~h}$ \\
\hline \multirow{3}{*}{$\begin{array}{c}\text { D-Fagomine } \\
(2.0 \mathrm{mg} / \mathrm{kg} \text { body weight })\end{array}$} & 1 & 88 & 100 & - & 72 & 47 & ND \\
\hline & 2 & 33 & - & 94 & 13 & traces & ND \\
\hline & 3 & 68 & - & 47 & ND & 17 & ND \\
\hline \multirow{3}{*}{$\begin{array}{c}\text { DNJ } \\
(2.0 \mathrm{mg} / \mathrm{kg} \text { body weight })\end{array}$} & 4 & 160 & - & - & - & - & 29 \\
\hline & 5 & 430 & - & - & - & 280 & 20 \\
\hline & 6 & 350 & - & - & - & 160 & 16 \\
\hline \multirow{3}{*}{$\begin{array}{c}\text { D-Fagomine } \\
\text { (10 mg/kg body weight) }\end{array}$} & 7 & - & 410 & - & 130 & 16 & ND \\
\hline & 8 & 620 & - & - & 450 & - & ND \\
\hline & 9 & 66 & - & - & 65 & 180 & ND \\
\hline \multirow{3}{*}{$\begin{array}{c}\text { DNJ } \\
(10 \mathrm{mg} / \mathrm{kg} \text { body weight })\end{array}$} & 10 & 580 & - & 650 & 99 & 33 & ND \\
\hline & 11 & 180 & - & 230 & 42 & ND & ND \\
\hline & 12 & 350 & 640 & - & 440 & 100 & ND \\
\hline \multirow{3}{*}{$\begin{array}{c}\text { D-Fagomine } \\
\text { (100 mg/kg body weight) }\end{array}$} & 13 & - & 660 & 380 & 220 & 48 & $<40$ \\
\hline & 14 & - & 730 & - & 490 & 170 & $<40$ \\
\hline & 15 & - & 2000 & 360 & 460 & 64 & $<40$ \\
\hline \multirow{3}{*}{$\begin{array}{c}\text { DNJ } \\
(100 \mathrm{mg} / \mathrm{kg} \text { body weight })\end{array}$} & 16 & - & - & 1100 & - & 570 & $<40$ \\
\hline & 17 & 240 & - & 660 & 120 & 63 & $<40$ \\
\hline & 18 & 230 & 1200 & 1300 & 400 & 90 & $<40$ \\
\hline
\end{tabular}

ND: Not detected; - collected at the next time point as the animal did not excrete urine during all collecting periods. 
Table 6. D-Fagomine and DNJ Concentration $(\mathrm{mg} / \mathrm{kg})$ in Feces Excreted in the 8-24 h Period after Oral Administration.

\begin{tabular}{|c|c|c|c|c|}
\hline & Rat & $6-8 \mathrm{~h}$ & $8-24 \mathrm{~h}$ & $48 \mathrm{~h}$ \\
\hline \multirow{3}{*}{$\begin{array}{c}\text { D-Fagomine } \\
(2.0 \mathrm{mg} / \mathrm{kg} \text { body weight })\end{array}$} & 1 & - & 32 & ND \\
\hline & 2 & ND & 110 & ND \\
\hline & 3 & ND & 170 & ND \\
\hline \multirow{3}{*}{$\begin{array}{c}\text { DNJ } \\
(2.0 \mathrm{mg} / \mathrm{kg} \text { body weight })\end{array}$} & 4 & ND & ND & ND \\
\hline & 5 & ND & 71 & ND \\
\hline & 6 & ND & 34 & ND \\
\hline \multirow{3}{*}{$\begin{array}{c}\text { D-Fagomine } \\
\text { (10 mg/kg body weight) }\end{array}$} & 7 & - & 750 & ND \\
\hline & 8 & - & 450 & ND \\
\hline & 9 & - & 890 & ND \\
\hline \multirow{3}{*}{$\begin{array}{c}\text { DNJ } \\
(10 \mathrm{mg} / \mathrm{kg} \text { body weight })\end{array}$} & 10 & ND & 150 & $\mathrm{ND}$ \\
\hline & 11 & ND & 650 & ND \\
\hline & 12 & - & 340 & ND \\
\hline \multirow{3}{*}{$\begin{array}{c}\text { D-Fagomine } \\
\text { (100 mg/kg body weight) }\end{array}$} & 13 & 5000 & 14000 & ND \\
\hline & 14 & 4000 & 9200 & ND \\
\hline & 15 & - & 8500 & ND \\
\hline \multirow{3}{*}{$\begin{array}{c}\text { DNJ } \\
(100 \mathrm{mg} / \mathrm{kg} \text { body weight })\end{array}$} & 16 & ND & 11000 & ND \\
\hline & 17 & ND & 8100 & $\mathrm{ND}$ \\
\hline & 18 & - & 6300 & ND \\
\hline
\end{tabular}

ND: Not detected; - collected at the next time point as the animal did not excrete feces during all collecting periods. 
Figure 1.
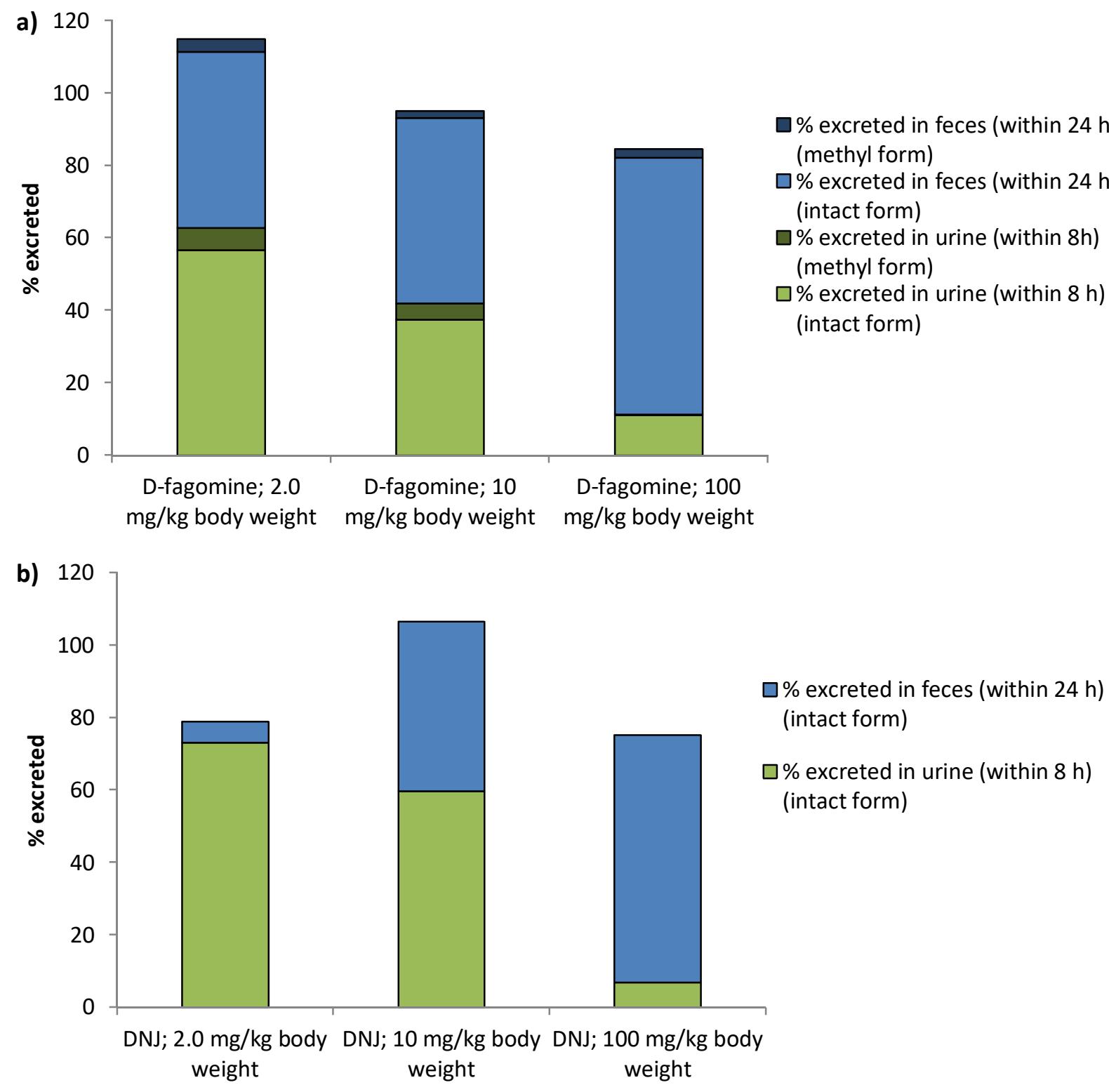
Figure 2.

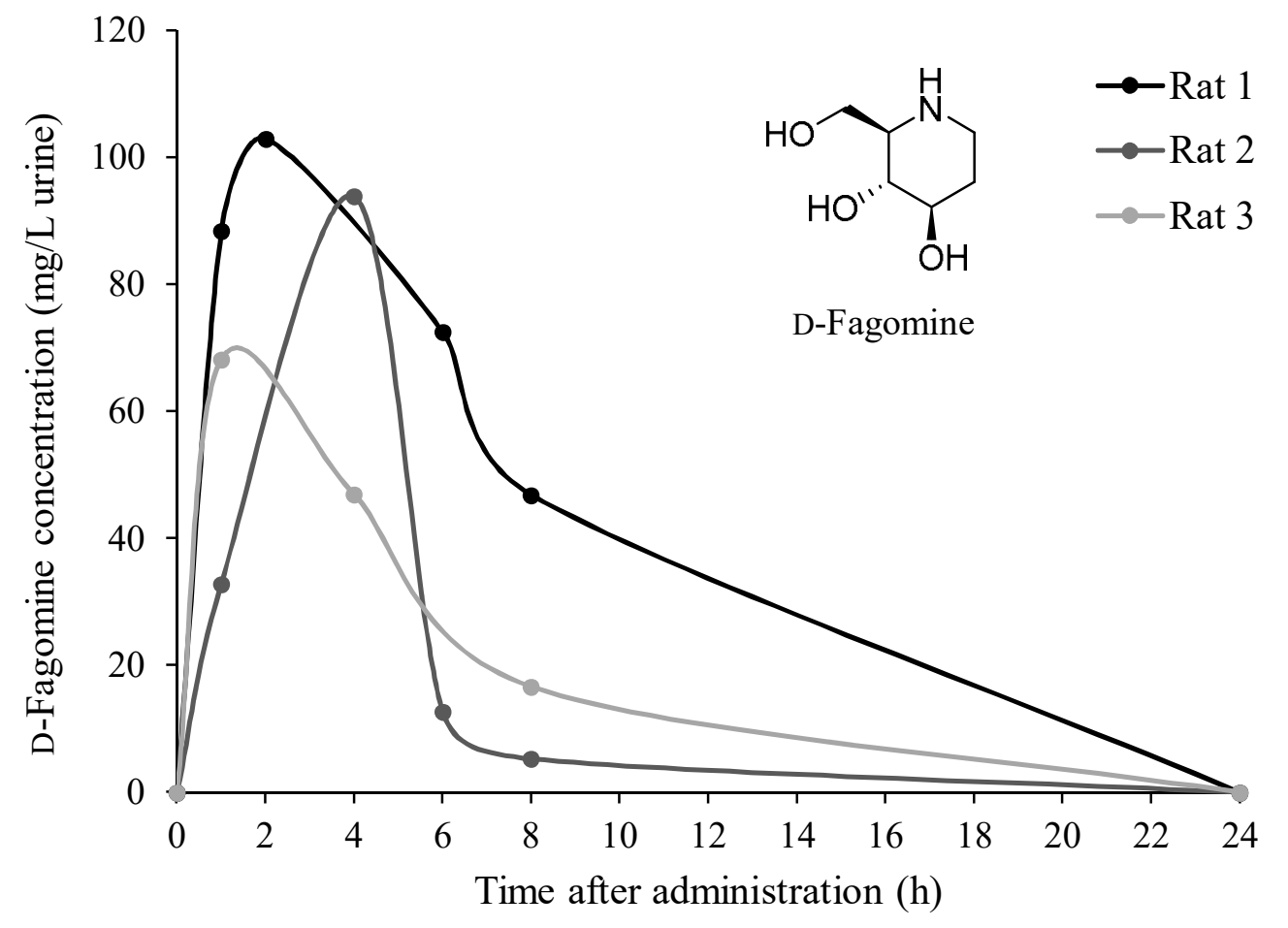


TABLE OF CONTENTS (TOC) GRAPHIC

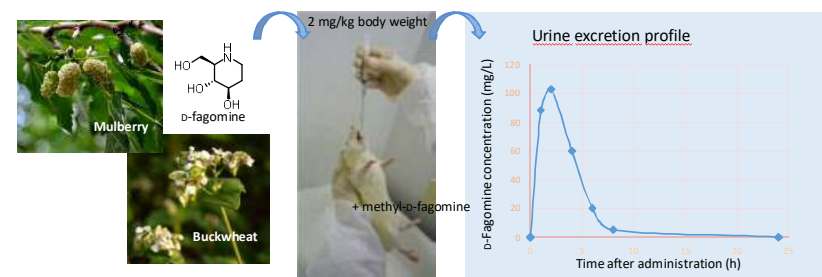

